Research note

\title{
First record of eucalyptus gall wasp Leptocybe invasa (Hymenoptera: Eulophidae) in Mexico
}

\section{Primer registro de la avispa agalladora del eucalipto Leptocybe invasa (Hymenoptera: Eulophidae) en México}

\author{
Juan Manuel Vanegas-Rico ${ }^{\text {a,*}}$, José Refugio Lomeli-Flores ${ }^{\text {a }}$, Esteban Rodríguez-Leyva ${ }^{\text {a }}$, \\ Eduardo Jiménez-Quiroz ${ }^{\mathrm{b}}$, Juli Pujade-Villar ${ }^{\mathrm{c}}$ \\ a Posgrado en Fitosanidad, Entomología y Acarología, Colegio de Postgraduados, Km 36.5, Carretera México-Texcoco, Montecillo, 56230 Texcoco, Estado de \\ México, Mexico \\ ${ }^{\mathrm{b}}$ Laboratorio de Análisis y Referencia en Sanidad Forestal, Dirección General de Gestión Forestal y de Suelos, Secretaría del Medio Ambiente y Recursos \\ Naturales, Av. Progreso Núm. 3, 04100 Coyoacán, México, D.F., Mexico \\ ${ }^{\mathrm{c}}$ Departamento de Biología Animal, Facultat de Biología, Universitat de Barcelona, Av. Diagonal 645, 08028 Barcelona, Spain
}

Received 6 April 2015; accepted 6 August 2015

Available online 6 November 2015

\begin{abstract}
The presence of the invader eucalyptus gall wasp Leptocybe invasa Fischer \& La Salle (Hymenoptera: Eulophidae) is recorded for the first time in Mexico. This forest pest has been detected in northern México City, at an elevation of $\approx 2,240 \mathrm{~m}$, with an average temperature of $17.9{ }^{\circ} \mathrm{C}$. It has also been detected in the areas of Nezahualcóyotl and Texcoco, State of México; Cuautla, Morelos; Guadalajara, Jalisco and Ciudad Victoria, Tamaulipas. In these states, L. invasa attacked Eucalyptus camaldulensis Dehnh. About 2.6\% of the E. camaldulensis trees reported in México City had infestations in about $27 \%$ of the twigs. In addition, $25 \%$ of the leaves had galls, with an average of $23.5 \pm 4.8$ galls per branches of $20 \mathrm{~cm}$ in length.

All Rights Reserved (C) 2015 Universidad Nacional Autónoma de México, Instituto de Biología. This is an open access item distributed under the Creative Commons CC License BY-NC-ND 4.0.

Keywords: Forest pest; Eucalyptus camaldulensis

\section{Resumen}

Se reporta por primera vez para México la avispa agalladora del eucalipto, Leptocybe invasa Fischer y La Salle (Hymenoptera: Eulophidae), plaga de importancia forestal. Esta plaga se ha detectado principalmente en el norte de la Ciudad de México a $\approx 2,240 \mathrm{~m}$ snm, a una temperatura promedio de $17.9^{\circ} \mathrm{C}$. También se detectó en Nezahualcóyotl y Texcoco, Estado de México; Cuautla, Morelos; Guadalajara, Jalisco y Ciudad Victoria, Tamaulipas. En estos estados, L. invasa atacó a Eucalyptus camaldulensis Dehnh. La incidencia de esta plaga en el arbolado urbano de la ciudad de México fue 2.6\%, con una severidad de $27 \%$ en ramas. Un $25 \%$ de las hojas presentaron agallas, con un promedio de $23.5 \pm 4.8$ agallas por rama de $20 \mathrm{~cm}$.

Derechos Reservados (C) 2015 Universidad Nacional Autónoma de México, Instituto de Biología. Este es un artículo de acceso abierto distribuido bajo los términos de la Licencia Creative Commons CC BY-NC-ND 4.0.
\end{abstract}

Palabras clave: Plaga forestal; Eucalyptus camaldulensis

\footnotetext{
* Corresponding author.

E-mail address: hymenopter@yahoo.com (J.M. Vanegas-Rico).

Peer Review under the responsibility of Universidad Nacional Autónoma de México.
}

Leptocybe invasa Fisher \& La Salle (Hymenoptera: Eulophidae) is a chalcidoid wasp of Australian origin that was originally detected inducing galls on eucalyptus trees in the Middle East (Mendel, Protasov, Fisher, \& La Salle, 2004). To date, this galler species occurs in 34 countries (FAO, 2009; Zheng et al., 2014). 


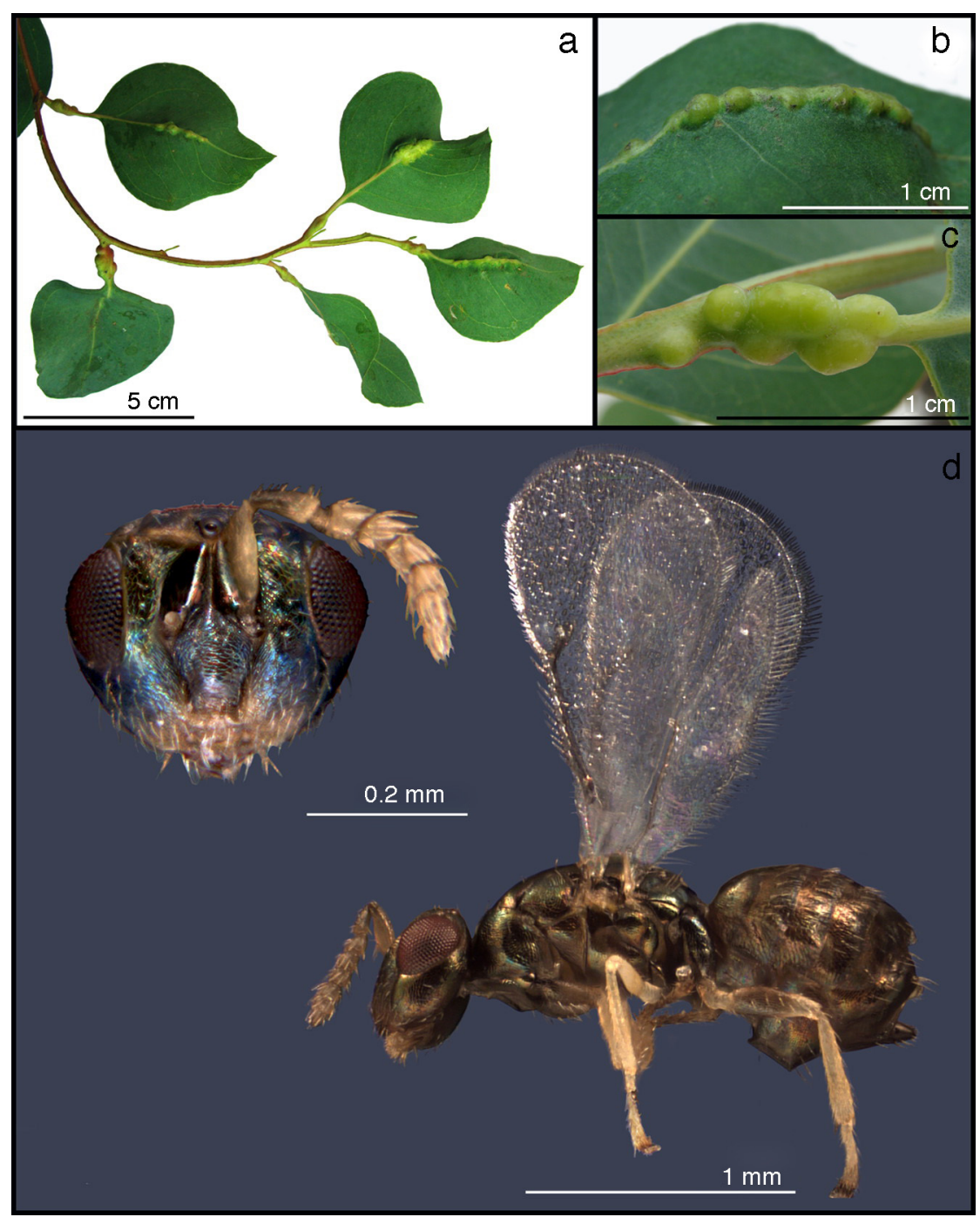

Figure 1. Damage of Leptocybe invasa in Eucalyptus camaldulensis. (a) Branch with galls; (b) leaf gall; (c) petiole gall; (d) L. invasa lateral view, frontal detail of the head.

L. invasa attacks several eucalyptus species and hybrid clones, inducing galls on leaves, petioles and 1-year-old branches, which reduces the vigor of the host and affects its growth, which may inflict serious economic losses (FAO, 2007; Mendel et al., 2004).

In August 2014, galls were detected on urban eucalyptus trees in the northern part of México City. Samples were taken from 1,100 trees distributed in areas where galls were detected. Sampling trees were selected at random at different points in the city. The sampling period lasted from December 2014 to March 2015. Tree species were identified using the key adapted by Gutiérrez, Sánchez, and Sandoval (2006). The presence or absence of galls was estimated for all of the selected trees, and 4 branches of $20 \mathrm{~cm}$ long each were removed at random from each infested tree. Severity was estimated using the following scale: null $=0 \%$, light $=<25 \%$, moderate $=25-50 \%$, severe $=>50 \%$ of the samples exhibiting galls (Nyeko, Mutitu, \& Day, 2009; Petro, Madfore, \& Iddi, 2014).

The plant material collected was labeled and placed in hermetically sealed plastic bags for transport to the Biological
Control Laboratory of the Colegio de Postgraduados, Texcoco, State of México. The material was kept in the laboratory at room temperature $\left(20 \pm 5^{\circ} \mathrm{C}\right)$, and the number of galls on leaves, petioles and branches were counted. The organisms that emerged from each sample were kept in $70 \%$ ethanol and identified by J. Pujade-Villar. Reference specimens were deposited at the Universidat de Barcelona, Spain, and the Colegio de Postgraduados, Mexico.

The hymenopteran species attacking the eucalyptus trees was identified as L. invasa (Fig. 1), and their host tree was identified as Eucalyptus camaldulensis Dehnh (Myrtales: Myrtaceae). This tree is abundant in México City (Cuello, Andorno, Hernández, Dell'Arciprete, \& Botto, 2014; Dittrich-Schröder, Wingfield, Hurley, \& Slippers, 2012; PAOT, 2013), and also has been recorded as a susceptible host attacked by this pest in different areas (Mendel et al., 2004; Nyeko et al., 2009; Petro et al., 2014). The incidence of $L$. invasa on E. camaldulensis was $2.6 \%$, mostly occurring in the northern area of México City. The branch severity was light $(<25 \%)$, with an average of $23.5 \pm$ 4.8 galls per branch. 
Table 1

Records of Leptocybe invasa in Mexico, July 2015.

\begin{tabular}{|c|c|c|c|c|}
\hline State & County & Latitude & Longitude & $\mathrm{m}$ asl \\
\hline \multirow[t]{6}{*}{ Distrito Federal (México City) } & Coyoacán & $19^{\circ} 19^{\prime} 22^{\prime \prime}$ & $99^{\circ} 10^{\prime} 32^{\prime \prime}$ & 2,281 \\
\hline & Gustavo A. Madero & $19^{\circ} 27^{\prime} 47^{\prime \prime}$ & $99^{\circ} 04^{\prime} 20^{\prime \prime}$ & 2,239 \\
\hline & Iztacalco & $19^{\circ} 24^{\prime} 18^{\prime \prime}$ & $99^{\circ} 07^{\prime} 11^{\prime \prime}$ & 2,257 \\
\hline & Iztapalapa & $19^{\circ} 21^{\prime} 14^{\prime \prime}$ & $99^{\circ} 05^{\prime} 20^{\prime \prime}$ & 2,282 \\
\hline & Venustiano Carranza & $19^{\circ} 27^{\prime} 09^{\prime \prime}$ & $99^{\circ} 06^{\prime} 52^{\prime \prime}$ & 2,246 \\
\hline & Xochimilco & $19^{\circ} 15^{\prime} 14^{\prime \prime}$ & $99^{\circ} 06^{\prime} 30^{\prime \prime}$ & 2,257 \\
\hline Jalisco & Guadalajara $^{\mathrm{a}}$ & $20^{\circ} 38^{\prime} 55^{\prime \prime}$ & $103^{\circ} 20^{\prime} 09^{\prime \prime}$ & 1,570 \\
\hline Morelos & Cuatla $^{\mathrm{a}}$ & $18^{\circ} 51^{\prime} 47^{\prime \prime}$ & $98^{\circ} 57^{\prime} 41^{\prime \prime}$ & 1,296 \\
\hline \multirow[t]{2}{*}{ State of México } & Nezahualcóyotl & $19^{\circ} 28^{\prime} 44^{\prime \prime}$ & $99^{\circ} 03^{\prime} 30^{\prime \prime}$ & 2,237 \\
\hline & Texcoco & $19^{\circ} 20^{\prime} 00^{\prime \prime}$ & $98^{\circ} 52^{\prime} 32^{\prime \prime}$ & 2,250 \\
\hline Tamaulipas & Ciudad Victoria $^{a}$ & $23^{\circ} 42^{\prime} 32^{\prime \prime}$ & $99^{\circ} 03^{\prime} 02^{\prime \prime}$ & 321 \\
\hline
\end{tabular}

a The material was collected by technicians of the Comisión Nacional Forestal (Conafor), Mexico.

Recently, a pest alert was emitted by the Secretaría del Medio Ambiente y Recursos Naturales (Semarnat) in Mexico for detection of this gall wasp on eucalyptus trees in the country (Semarnat, 2015). The first inspection recorded the presence of $L$. invasa in other localities (Table 1), though the incidence and severity were not evaluated. Actually, a national integrated management program is being developed for this plague, the introduction of parasitoids is being considered, since natural enemies of $L$. invasa have not been collected in Mexico. The damage inflicted by this gall wasp varies according to the different eucalyptus producing regions (Nyeko, Mutitu, Otieno, Ngae, \& Day, 2010; Petro et al., 2014), probably due to a combination of factors such as host susceptibility, host age and altitude of the area where the trees are cultivated (Dittrich-Schröder et al., 2012; Nyeko et al., 2009; Petro et al., 2014). The highest altitude where the pest has been documented was in Uganda at 2,000 m (Mutitu, Nyeko, Day, Otieno, \& Oeba, 2007). For this reason, it is likely that the altitude $(2,236-2,290 \mathrm{~m})$ and temperature $\left(17.9 \pm 0.3^{\circ} \mathrm{C}\right)$ of México City, and the age of the infested trees of E. camaldulensis ( $>10$ years) negatively affect $L$. invasa infestation.

This represents the first record of $L$. invasa for the Mexican territory, and it is the seventh report of this wasp species in the American continent. Previously, it had been reported in Brazil (Costa et al., 2008), USA (Wiley \& Skelley, 2009), Argentina (Aquino, Botto, Loiácono, \& Pathauer, 2011), Chile (Wylie \& Speight, 2012), Uruguay (Jorge, Gómez, \&MartínezCrosa, 2014) and Paraguay (Benítez, Costa, de Moraes, \& Godziewsky, 2014). Moreover, our records for Mexico represent the first occurrence of this species at an altitude higher than $2,000 \mathrm{~m}$. So far, $L$. invasa has been mostly detected in northern México City. This report remarks the importance to carry out sanitary inspection programs of the urban wooded areas in México City, and to monitor the main eucalyptus producing regions of this country, which together comprise 31,000 ha distributed along the coasts of both the Gulf of Mexico (59\%) and the Pacific (36\%) (Conafor, 2014).

The authors gratefully acknowledge Geog. Martha Eugenia Luna Mar and Ing. Oscar Trejo Ramírez from Dirección General de Gestión Forestal y de Suelos, Semarnat, for allowing us to use official information of this pest.

\section{References}

Aquino, D. A., Botto, E. N., Loiácono, M. S., \& Pathauer, P. (2011). "Avispa de la agalla del Eucalipto", Leptocybe invasa Fischer \& Lasalle (Hymenoptera: Eulophidae: Tetrastichinae) en Argentina. Revista de Investigaciones Agropecuarias, 37, 159-164.

Benítez, E. A., Costa, V. A., de Moraes, G. J., \& Godziewsky, D. (2014). First record of Leptocybe invasa Fisher \& La Salle (Hymenoptera: Eulophidae) and Rhombacus eucalypti Ghosh \& Chakrabarti (Acari: Eriophyidae) from Paraguay. Boletín del Museo Nacional de Historia Natural de Paraguay, 18, $129-132$.

Conafor (Comisión Nacional Forestal). (2014). Plantaciones forestales comerciales establecidas de Eucaliptus 1997-2014 Documento interno. México, D.F.: Conafor.

Costa, V. A., Filho, E. B., Wilcken, C. F., Stape, J. L., La sale, J., \& Teixeira, L. (2008). Eucaliptus gall wasp, Leptocybe invasa Fisher \& Lasalle (Hymenoptera: Eulophidae) in Brazil: New forest pest reaches the New World. Revista de Agricultura, 83, 136-139.

Cuello, E., Andorno, A. V., Hernández, C. M., Dell'Arciprete, V., \& Botto, E. N. (2014). Primeros estudios sobre asociaciones tróficas de interés para la sanidad forestal en Eucaliptus spp. Revista de la Sociedad Entomológica Argentina, 73, 183-186.

Dittrich-Schröder, G., Wingfield, M. J., Hurley, B. P., \& Slippers, B. (2012). Diversity in Eucaliptus susceptibility to the gall-forming wasp Leptocybe invasa. Agricultural and Forest Entomology, 14, 419-427.

FAO (Organización de las Naciones Unidas para la Alimentación y la Agricultura). (2007). Forest pest species profile: Leptocybe invasa, blue grum Chalcid (Hymenoptera: Eulophidae).. Retrieved from http://www.fao.org/forestry/13569-068609a4a4b1e3643e6ae4c2c45099b8. pdf (accessed 17.02.15)

FAO (Organización de las Naciones Unidas para la Alimentación y la Agricultura). (2009). Global review of forest pest and diseases: a thematic study prepared in the framework of the global forest resources assessment 2005 FAO Forestry Paper 156. Rome, Italy: FAO. Retrieved from ftp://ftp.fao.org/docrep/fao/011/i0640e/i0640e.pdf (accessed 10.02.15)

Gutiérrez, M., Sánchez, G., \& Sandoval, L. (2006). Eucaliptos que habitan en el norte y centro de México: manual para su identificación Libro técnico Núm. 3. Aguascalientes: Centro de Investigación Regional Norte Centro, Campo Experimental Pabellón. Inifap.

Jorge, C., Gómez, D., \& Martínez-Crosa, G. (2014). La avispa agalladora del eucalipto Leptocybe invasa: reconocimiento, daños y posibles estrategias de manejo Serie Técnica 213. Tacuarembó, Uruguay: Instituto Nacional de Investigación Agropecuaria.

Mendel, Z., Protasov, A., Fisher, N., \& La Salle, J. (2004). Taxonomy and biology of Leptocybe invasa gen \& sp. n. (Hymenoptera: Eulophidae), an invasive gall inducer on eucalyptus. Australian Journal of Entomology, 43, 101-113.

Mutitu, K. E., Nyeko, P., Day, R. K., Otieno, B. O., \& Oeba, V. (2007). Distribution, incidence and severity patterns of blue gum chalcid, Leptocybe invasa in east Africa. In 1st Executive committee 
meeting of the forestry invasive species network for Africa (FISNA), and USDA Forest Service Pietermaritzburg, South Africa,. Retrieved from http://www.fao.org/forestry/12725-01fa3b83fe44e68c554d2d8c6e3d481cc. pdf (accessed 15.02.15)

Nyeko, P., Mutitu, K. E., \& Day, R. K. (2009). Eucalyptus infestation by Leptocybe invasa in Uganda. African Journal of Ecology, 47, 299-307.

Nyeko, P., Mutitu, K. E., Otieno, B. O., Ngae, G. N., \& Day, R. K. (2010). Variations in Leptocybe invasa (Hymenoptera: Eulophidae) population intensity and infestation on eucalyptus germplasms in Uganda and Kenya. International Journal of Pest Management, 56, 137-144.

PAOT (Procuraduría Ambiental y del Ordenamiento Territorial del D.F.). (2013). Censo del arbolado ubicado sobre el eje 3 oriente (Eduardo Molina), tramo comprendido del Río de los Remedios a San Lázaro, delegaciones Gustavo A. Madero y Venustiano Carranza. México, D.F.: PAOT

Petro, R., Madfore, S. S., \& Iddi, S. (2014). Infestation density of eucalyptus gall wasp, Leptocybe invasa Fisher and La Salle (Hymenoptera: Eulophidae) on 5 commercially grown eucalyptus species in Tanzania. Journal of Sustainable Forestry, 33, 276-297.
Semarnat (Secretaría de Medio Ambiente y Recursos Naturales). (2015). Alerta fitosanitaria: avispa agalladora del eucalipto (Leptocybe invasa). México, D.F.: Laboratorio de Análisis y Referencia en Sanidad Forestal, Semarnat. Retrieved from http://www.conafor.gob.mx:8080/documentos/ docs/15/6201Leptocybe\%20invasa.pdf

Wiley, J., \& Skelley, P. (2009). A eucalyptus pest, Leptocybe invasa Fisher and La Salle (Hymenoptera: Eulophidae), genus and species new to Florida and North America. Florida Department of Agriculture and Consumer Services (US). Pest Alert. Retrieved from http://www.freshfromflorida.com/ Divisions-Offices/Plant-Industry/Plant-Industry-Publications/Pest-Alerts/ Pest-Alerts-A-Eucalyptus-Pest-Leptocybe-Invasa (accessed 22.02.15)

Wylie, F. R., \& Speight, M. R. (2012). Insects pest in tropics forestry (2nd ed.). Wallingford, UK: CABI.

Zheng, X. L., Li, L., Yang, Z. D., Xian, Z. H., Wei, J. G., Lei, C. L., et al. (2014). A review of invasive biology, prevalence and management of Leptocybe invasa Fisher \& La Salle (Hymenoptera: Eulophidae: Tetrastichinae). African Entomology, 22, 68-79. 